\title{
Influence of varietal associations on the development of leaf and glume blotch and brown leaf rust in winter bread wheat
}

\author{
B Mille ${ }^{1 *}$, B Jouan ${ }^{2}$ \\ ${ }^{I}$ Service de recherches intégrées sur les productions végétales et la protection des plantes, Inra, 78026 Versailles cedex, \\ ${ }^{2}$ Service de recherches intégrées sur les productions végétales et la protection des plantes, Inra, BP 29, 35650 Le Rheu, France
}

(Received 15 March; accepted 12 May 1997)

\begin{abstract}
Summary - In order to reduce fungicide sprays, different methods can be used. Among them, variety mixtures are efficient against Puccinia striiformis on winter wheat. We have estimated their efficacity at controlling Septoria spp and Puccinia recondita: the experimental mixtures reduced diseased leaf area by up to $8 \%$, and increased yield by about $7 \%$.
\end{abstract}

Septoria nodorum / Septoria tritici / Puccinia striiformis / variety mixture

Résumé - Influence des associations variétales sur le développement des septorioses et de la rouille brune du blé tendre d'hiver. Pour limiter les pulvérisations fongicides foliaires, différentes techniques sont utilisables et, parmi elles, les associations variétales dont l'efficacité a déjà été démontrée vis-à-vis de la rouille jaune (Puccinia striiformis) du blé tendre d'hiver. Nous avons évalué leur intérêt face à d'autres maladies foliaires, les septorioses (Septoria nodorum et Septoria tritici) et la rouille brune (Puccinia recondita) : les associations variétales expérimentées permettent de réduire les surfaces foliaires nécrosées jusqu'à plus de $8 \%$ et d'augmenter le rendement d'environ $7 \%$.

Septoria nodorum / Septoria tritici / Puccinia striiformis / association variétale

\section{INTRODUCTION}

The sales price from large-scale production operations has been steadily diminishing in recent years. This has been accompanied by a thorough reconsideration of cropping systems, if only to maintain a sufficient profit margin. The growing concern for the environment, and particularly for the quality of both surface and ground water, raises questions connected with the substances applied to fields (fertilizers, pesticides) and their

* Correspondence and reprints

Tel: (33) 01308335 65; fax: (33) 01308335 62; e-mail: mille@versailles.inra.fr 
contribution to pollution. The maintenance of the profit margin and concern for the environment press for a reduction in inputs, of which foliar fungicides are a substantial part. During the last 20 years, yield stability has been basically maintained by chemical protection, since varietal resistance to fungal diseases remains weak over time. Farming in our country has managed these resistances poorly, and this failure suggests a rediversification through the cultivation of associated varieties in the production of wheat and barley. Studies have been conducted in a number of countries: Switzerland (Fried and Streckeisen, 1986), Germany (Gieffers and Hesselbach, 1987), Wales (Jeger et al, 1981), England (Wolfe and Barett, 1980; Wolfe and Limpert, 1990), etc. This technique of varietal association has also been studied in France (De Vallavielle-Pope et al, 1991): the research has basically been carried out on the possibility of retarding the development of yellow rust.

We have studied the possibility of reducing the number of foliar fungicide sprayings and we have evaluated the interest of this technique in combatting other foliar diseases, mainly leaf and glume blotch caused by Septoria nodorum and Septoria tritici, as well as leaf rust caused by Puccinia recondita. These diseases are taken into special consideration in our studies for the following reasons: leaf and glume blotch is present everywhere on bread winter wheat and, even though it does not always seem to have a very harmful effect, yield losses are regularly estimated at between 10 and 25\% (de La Roque and Murer, 1989) and may reach 4 tons/ha (Seng et al, 1994). The best fungicidal products have a limited efficacity on this pathogenic agent, rarely exceeding $70 \%$. Consequently, a cultivation system that limits the development of pathogens may be of particular interest. Brown rust establishes itself naturally on the test fields during the second half of May.

\section{MATERIAL AND METHODS}

\section{Choice of associated varieties}

The varietal associations should optimize the level of final production by agronomical homogeneity and provide the best level of general resistance to the diseases. There are five criteria of choice (Meynard, pers comm): productivity; uniform baking value (superior breadmaking quality); uniform heading and uniform straw height to avoid competition between cultivars; uniform maturity; and complementary resistances to major pathogens. The demands of these criteria are
Table I. Resistance scores concerning major foliar diseases of cultivars in pure stands (ITCF, 1993).

\begin{tabular}{lccc}
\hline Cultivars $^{a}$ & $\begin{array}{c}\text { Yellow }^{\text {rust }}{ }^{b} \\
\text { Soissons }\end{array}$ & $\begin{array}{c}\text { Septoria } \\
\text { leaf blotch }\end{array}$ & $\begin{array}{c}\text { Brown } \\
\text { rust }\end{array}$ \\
\hline Delfi & 5 & 6 & 1 \\
Pactole & 2 & 4 & 5 \\
\hline
\end{tabular}

a Varieties scored from 1 (low level of resistance) to 9 (very good level of resistance); ${ }^{b}$ the varieties were initially chosen for their resistance to yellow rust; ${ }^{\circ}$ caused by Septoria nodorum on leaves and ears.

such that the varietal choice is restricted and only two associations have been selected: one binary, of Soissons $(1 / 2)+$ Delfi $(1 / 2)(S+D)$, and the other ternary, of Soissons $(1 / 3)+$ Delfi $(1 / 3)+$ Pactole $(1 / 3)$ $(\mathrm{S}+\mathrm{D}+\mathrm{P})$. The characteristics of these varieties, which were also tested against yellow rust by the Epidemiology Service of Inra Grignon, are outlined in table I.

\section{Research methods}

The test arrangement was set up in a field at the La Verrière experimentation site (78) for three consecutive years (1992-1994); it consisted of small plots $\left(20 \mathrm{~m}^{2}\right)$ arranged in blocks (four repetitions).

The natural contamination of Septoria (S nodorum and $S$ tritici) was strengthened artificially (spraying of about $25 \mathrm{~cm}^{3} / \mathrm{m}^{2}$ of a spore suspension calibrated at $10^{6}$ spores $/ \mathrm{mL}$ ) during the course of March to obtain sufficient disease development, uniformly distributed in each block. The spores were produced by multiplication in the laboratory in Petri dishes of isolates obtained at the experimentation site. Depending on the conditions each year, the brown rust established itself naturally towards the end of May.

Observations were recorded by visual evaluation of the percentage of necrotic surface in each leaf stage reached (except senescent), at three points in the year (in the first and second half of May, and in June). Fifty plants were taken from each basic plot but the main shoot alone was recorded. The fields were uniformly harvested at maturity for a yield assessment. The results obtained on the varietal associations were compared (by variance analysis) with a theoretical value equal to the average of the observations made on the pure varieties. The results presented here were obtained from fields that had received no active foliar fungicide treatment against leaf diseases. 


\section{RESULTS}

\section{Plant health situation in 1992, 1993 and 1994:} evolution of the diseases on the pure cultivars

The situation was different each year (table II):

- in 1992 leaf blotch was well established and remained dominant with respect to the other foliar diseases (an average 32\% necrotic surface (NS) on the two top leaves),

- in 1993 leaf blotch was at first dominant before brown rust erupted and finally became the main factor of foliar necrosis (average $86 \%$ NS),

- in 1994 leaf blotch developed regularly over the course of the year; brown rust was present but

Table II. The development of foliar diseases on pure cultivars without foliar fungicide protection in the period 1992-1994.

\begin{tabular}{lccc}
\hline & & Year & \\
& 1992 & 1993 & 1994 \\
\hline Septoria leaf blotch & +++ & + & ++ \\
Brown leaf rust & 0 & +++ & + \\
$\%$ SN in june & 32 & 86 & 25 \\
\hline
\end{tabular}

$+=$ notable presence of the disease $+++=$ very extensive development of the disease; $\% \mathrm{SN}=$ percentage of average necrotic surface on F1 and F2 of pure varieties. its progress was hindered by frequent rain (average $25 \%$ NS).

Over the course of these 3 years, the identification of the fruiting bodies found in the foliar necroses revealed the predominant presence of $S$ tritici; $S$ nodorum was only observed, after flowering had finished, on less than $3 \%$ of the necroses observed in the fields.

\section{Influence of the varietal associations on the development of foliar diseases}

The differences between the various test fields were difficult to demonstrate (the effects connected with the varietal mix being rarely statistically significant) before June. Since the period following the end of flowering provides the most discriminating observations, we only present the observations from June onwards, but at this stage the necroses due to Septoria can no longer be distinguished from those of brown rust.

The balance of the 3 years is as follows: in the absence of foliar fungicidal treatment, disease development was low in the varietal associations with respect to that observed in the pure stands (fig 1). The reduction of the percentage of necrotic surface was an average of $5.6 \%$, ranging from 0.6 to $8.3 \%$. It appears to be more homogeneous for the ternary association $(4-7 \%)$ than for the binary association $(0.6-8.3 \%)$.

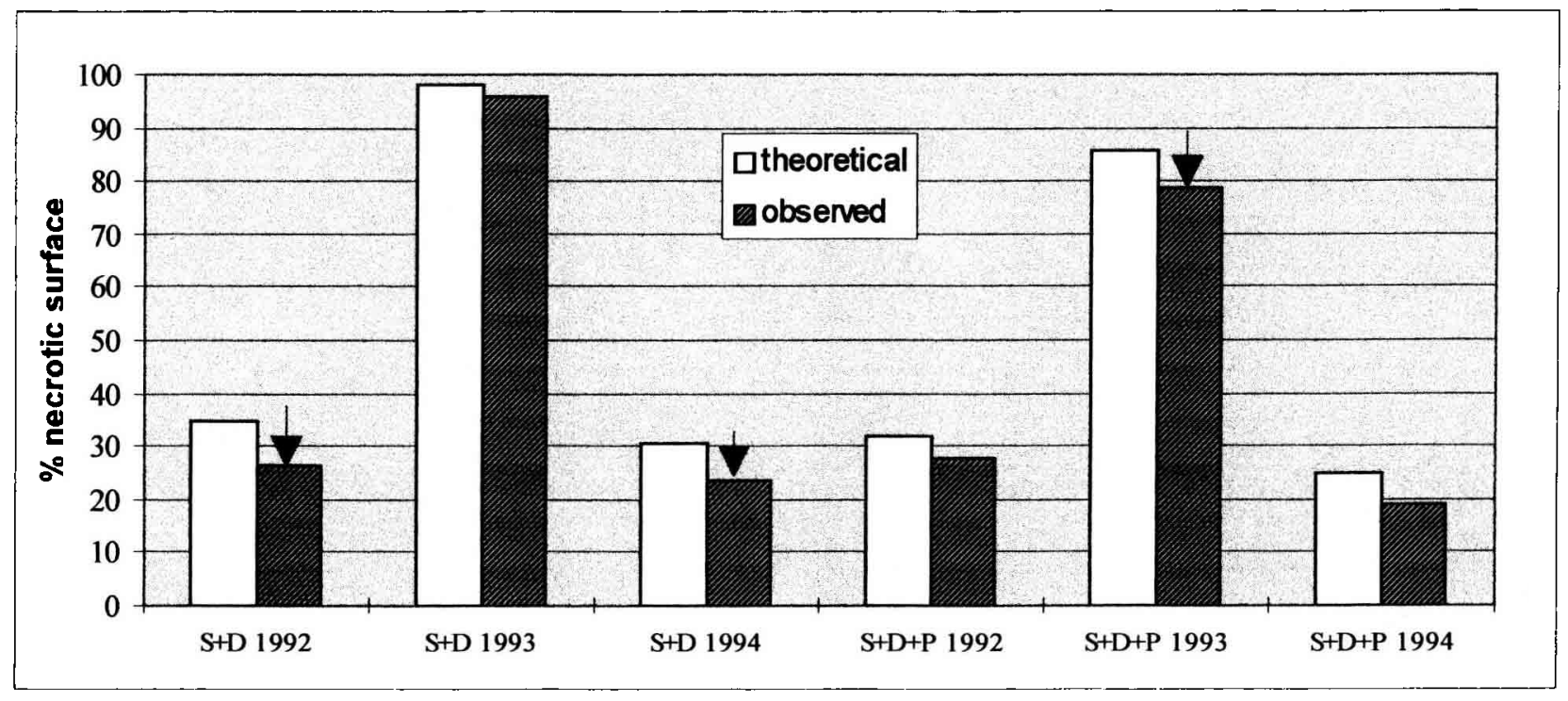

Fig 1. Theoretical and observed necrotic surface on the two top leaves at the end of June. $S+D=\operatorname{mix}$ of Soissons and Delfi; $\mathrm{S}+\mathrm{D}+\mathrm{P}+=\operatorname{mix}$ of Soissons, Delfi and Pactole; theoretical value $=$ average of observations made on pure varieties; $\rightarrow$ : statistically significant difference with respect to the theoretical mix (ppds $=6.7$ ). 


\section{Influence of varietal associations on yields}

As for the observations of necroses, a theoretical yield was calculated as the mean of the yields obtained in pure stands.

In 1992, an outbreak of Gaeumannomyces graminis levelled the production of the whole set of fields so the respective results are not presented.

In 1993 and 1994, the increased yield in the case of binary and ternary associations was an average $7.4 \%$ (fig 2), ranging from 4.6 to $9.5 \%$. Contrary to what was seen with the foliar necroses, it appears to be more stable for the binary association ( 7.8 and $8 \%$ ) than for the ternary association (4.6 and 9.5\%). The analysis of the weight of 1000 grains did not reveal any statistically significant effects of the associations.

\section{DISCUSSION AND CONCLUSION}

The preceding studies (de Vallavieille-Pope et al, 1991) proved the action of varietal associations on the reduction of the development of yellow rust. Our results confirm that these associations offer the same type of interest with respect to leaf blotch and brown rust. The limitation of the development of the disease translates into a smaller necrotic leaf surface in the case of varietal associations. There is also a beneficial effect on yields since they increase by over $7 \%$. As for other foliar diseases, the associations studied allowed a reduction of losses by limiting epidemic development.

As in our neighbouring countries, the varietal association technique may be used with varieties chosen from among those widely cultivated in France while meeting the criteria of agronomical compatibility. It should be recalled that this technique does not present any special difficulty. The farmer himself may make the varietal association and it does not involve any extra expense. It can allow reduced inputs, affording the possibility of diminishing or eliminating foliar fungicide sprayings when the plant health conditions permit. It may also bring about increased yields without requiring any extra input investments.

The varietal association technique presents a low level of effectiveness but it helps to limit plant health risks. It can supplement the action of other techniques (agronomical methods, varietal resistances, chemical treatments of seed, etc) and should form part of integrated protection systems. It may also be of interest in connection with biological agriculture. In the long term, this technique should lengthen the time of use of varieties, especially by retarding the decrease in varietal resistance levels (a decrease linked to the selection of pathogens that are virulent with respect to the varieties most often sowed). Moreover, by allowing a reduction of fungicidal interventions, the risk of the production of pathogens resistant to the fungicides may be reduced (Forrer and Grindat, 1985).

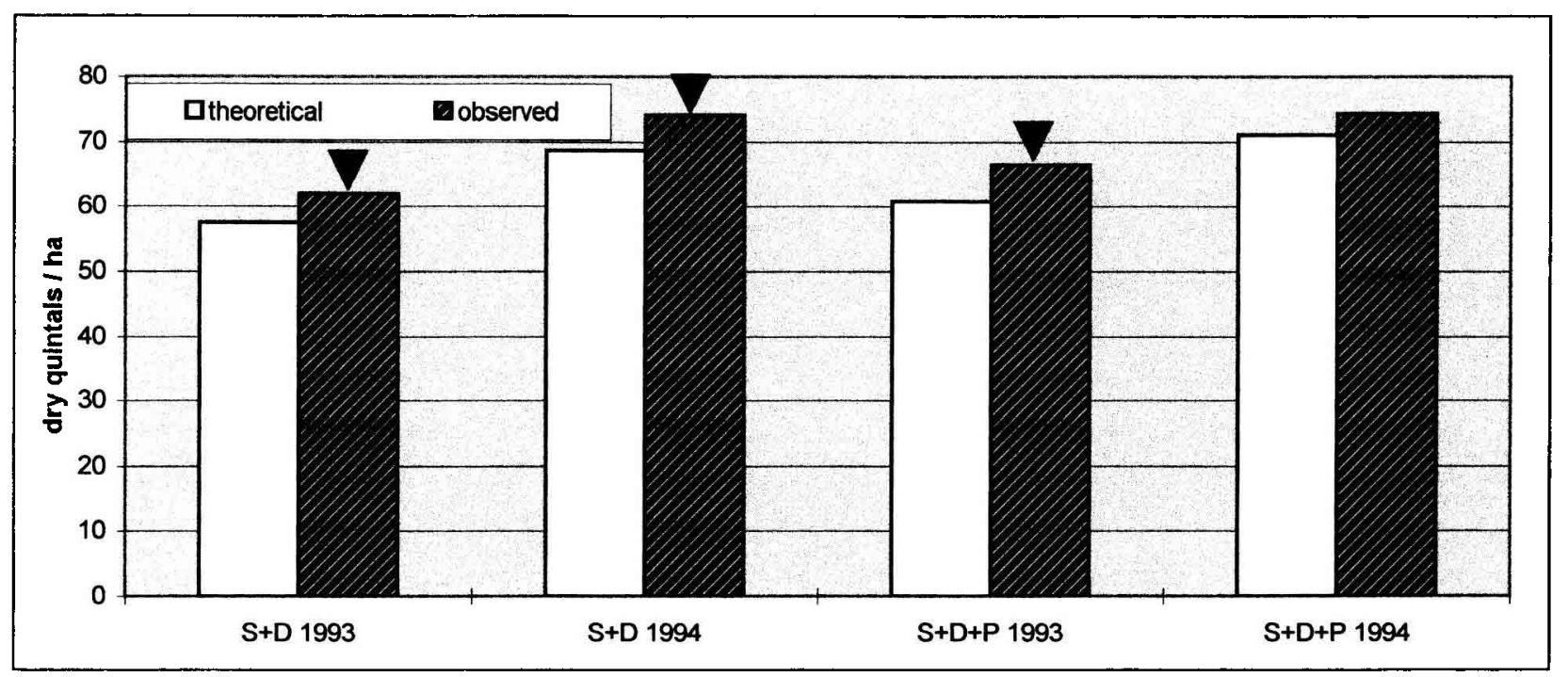

Fig 2. Theoretical and observed yields of the varietal associations. $S+D=\operatorname{mix}$ of Soissons and Delfi; $S+D+P=$ mix of $S o i s s o n s$, Delfi and Pactole; dry quintals $=$ yield expressed as quantity of dry matter $(0 \%$ moisture $)$; theoretical value $=$ average of the observations made on pure varieties; $\rightarrow$ : statistically significant difference with respect to the theoretical mix $(\mathrm{ppds}=4.6$ ). 


\section{REFERENCES}

Forrer HR, Grindat D (1985) Strategie zur Vermeidung von Fungizidresistenz im Getreidebau. Mitt Schweiz Landw 33, 39-51

Fried PM, Streckeisen P (1986) Mélanges de variétés en céréaliculture : expériences internationales et résultats des essais suisses faits de 1982 à 1985 sur les variétés de blé d'automne Arina, Eiger, Sardona et Zenta. Rev Suisse Agric 18, 317-320

Gieffers W, Hesselbach J (1987) Krankheit und Ertrag verschiedener Getreidesorten im Rein-und Mischanbau. I. Sommergerste (Hordeum vulgare L). Zeitschrift für Pflanzenkrankheiten und Pflanzenschutz, 46-62

ITCF (1993) Variétés de céréales 1993, 23 p

Jeger MJ, Gareth Jones D, Ellis Griffiths (1981) Disease progress of non-specialised fungal pathogens in intraspecific mixed stands of cereal cultivars II. Field experiments. Ann Appl Biol 98, $199-210$

de La Roque B, Murer F (1989) Septorioses des céréales, prévoir les dates de traitement. Cultivar $246,42-46$

Seng JH, Desmarais S, Barchietto T (1994). Les septorioses du blé : des maladies d'avenir. Phytoma $464,21-23$

de Vallavieille-Pope C, Goyeau H, Lannou C, Mille B (1991) La culture de céréales en mélange pour lutter contre les maladies foliaires. Phytoma 424, 2836

Wolfe MS, Barrett JA (1980). Can we lead the pathogen astray? Plant Disease 64, 148-155

Wolfe MS, Limpert E (1990). Vers une meilleure ma"trise des populations d'oïdium des céréales. Rev Suisse Agric 22, 139-144 